Original Article

\title{
Phytochemical screening and preliminary clinical trials of the aqueous extract mixture of Andrographis paniculata (Burm. f.) Wall. ex Nees and Syzygium polyanthum (Wight.) Walp leaves in metformin treated patients with type 2 diabetes
}

\author{
Elisabeth Catherina Widjajakusuma ${ }^{\mathrm{a}, \mathrm{b}, *}$, Arijanto Jonosewojo, ${ }^{\mathrm{c}, \mathrm{d}}$, Lucia Hendriati ${ }^{\mathrm{b}}$, Sumi Wijaya ${ }^{\mathrm{b}}$, \\ Ferawati $^{\mathrm{a}}$, Adrianta Surjadhana ${ }^{\mathrm{b}}$, Widayat Sastrowardoyo ${ }^{\mathrm{c}, \mathrm{d}}$, Nadia Monita ${ }^{\mathrm{d}}$, \\ Nafdsu Makhmudatul Muna ${ }^{\mathrm{d}}$, Rachma Pantja Fajarwati ${ }^{\mathrm{d}}$, Martha Ervina ${ }^{\mathrm{b}}$, Senny Yesery Esar ${ }^{\mathrm{b}}$, \\ Lisa Soegianto $^{\mathrm{b}}$, Tirza Lang ${ }^{\mathrm{b}}$, Cindy Heriyanti ${ }^{\mathrm{b}}$ \\ ${ }^{a}$ Research Center for Traditional Medicine, Widya Mandala Catholic University Surabaya, Jl. Dinoyo 42-44, Surabaya 60265, Indonesia \\ ${ }^{\mathrm{b}}$ Faculty of Pharmacy, Widya Mandala Catholic University Surabaya, Jl. Raya Kalisari Selatan No.1, Surabaya 60112, Indonesia \\ ${ }^{\mathrm{c}}$ Faculty of Medicine, Airlangga University, Jl. Mayjen Prof. Dr. Moestopo No. 47, Surabaya 60286, Indonesia \\ dindonesian Traditional Medicine Polyclinic, Dr. Soetomo General Hospital, Jl. Mayjen Prof. Dr. Moestopo No. 6-8, Surabaya, 60286, Indonesia
}

\section{A R T I C L E I N F O}

\section{Keywords:}

Andrographis paniculata

Syzygium polyanthum

Type 2 diabetes mellitus

GC-MS

Clinical study

Metformin

\begin{abstract}
A B S T R A C T
Background: Our previous preclinical study showed that the extract mixture (EM) of Andrographis paniculata (Burm. f.) Wall. ex Nees (AP) and Syzygium polyanthum (Wight.) Walp (SP) leaves had antidiabetic effects and were beneficial on alloxan-induced diabetic rats.

Purpose: The objectives of this study were to: 1) identify the phytochemical compounds present in aqueous extract of AP and SP and 2) examine the benefits of the EM of AP and SP leaves in lowering blood glucose in the presence of standard antidiabetic treatment using metformin in type 2 diabetic patients in Indonesian Traditional Medicine Polyclinic of Dr. Soetomo General Hospital in Surabaya.

Methods: Phytochemical analysis of aqueous leaf extract of AP and SP was performed using standard chemical tests, TLC, and GC-MS. Furthermore, a total of 54 subjects with T2DM participated in this study and were randomly assigned to either the intervention group supplemented with the extract mixture of AP and SP at a dose $900 \mathrm{mg} / \mathrm{day}$ for 8 weeks, or the control group which received placebo tablets in a randomized placebo-controlled double-blinded parallel clinical trial. Both groups received metformin at dose $1000 \mathrm{mg} /$ day. Body weight, blood pressure, fasting blood glucose, postprandial glucose, haemoglobin A1c, triglycerides, total cholesterol, low density lipoprotein, high density lipoprotein, and markers of liver and kidney damage were measured.

Results: The results of phytochemical analysis showed that the glycosides, terpenoids, alkaloids, flavonoids, saponins, and tannins were found to be present in the extract mixture. GC-MS analyses of AP and SP showed the presence of 19 and 12 peaks, respectively. Methyl ester of 9-octadecenoic and eicosanoic acid were determined as the main constituents of both species. Moreover, the results of clinical study suggested that the extract mixture improved the decrease of fasting blood glucose and postprandial glucose, significantly lowered body mass index compared with the control group. The EM appeared beneficial for SGPT values and uric acid levels.

Conclusion: Overall, the results of this study suggested the potential beneficial effects of the extract mixture for use as complementary medicine alongside conventional treatment of metformin. The extract mixture contained many highly potent compounds for treating T2DM and preventing short- and long-term risk complications of diabetes.
\end{abstract}

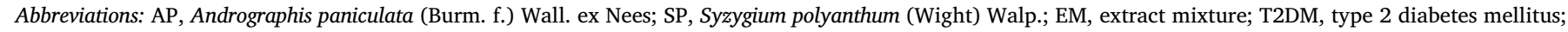

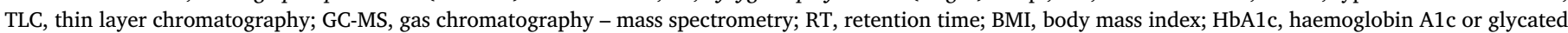

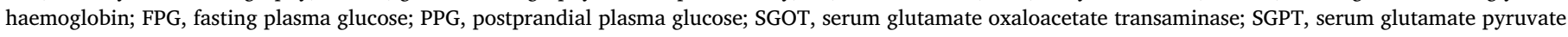
transaminase; GGT, gamma-glutamyltransferase

* Corresponding author at: Faculty of Pharmacy, Widya Mandala Catholic University Surabaya, Jl. Raya Kalisari Selatan No. 1, Surabaya, Indonesia.

E-mail address: ecwidj@ukwms.ac.id (E.C. Widjajakusuma). 


\section{Introduction}

Diabetes mellitus is becoming a serious complex chronic condition that is a major health problem owing to the advancing age of population, a substantially increased prevalence of obesity, and decreased physical activity (Danaei et al., 2011). In Asia, the type 2 diabetes mellitus (T2DM) has reached epidemic proportions characterized by rapid rates of increase over short periods and onset at a relatively young age and low body mass index (Chan et al., 2009; Ramachandran et al., 2012). The important feature of diabetes is an elevated blood sugar level (hyperglycemia) associated in approximately $90 \%$ of T2DM with other cardiovascular factors, that constitute the metabolic syndrome. For a significant number of patients, the treatment of T2DM must include pharmacological agents in order to reach satisfactory glycemic control.

Since 1950, metformin, an oral hypoglycemic agent, has been recommended as first line pharmacotherapy to treat diabetic patients (Holman, 2007; Wendy et al., 2011). Furthermore, metformin has also been shown in studies to lower the risk of other complications of diabetes such as a substantial beneficial effect on cardiovascular, lipid profile and arterial blood pressure of diabetic patients (MourãoJúnior et al., 2006). Although it is infrequent, lactic acidosis is the main serious metabolic risk associated with metformin overdose (Lheureux et al., 2009). Many diabetic patients in inadequate long-term blood glucose control with metformin monotherapy require additional treatment (Goldstein et al., 2003; Marre et al., 2002; Ponssen et al., 2000). On another side, there has been an increasing interest in the use of medicinal plants products for treating type 2 diabetic patients in the recent years (Bahmani et al., 2014; Mirhoseini et al., 2013; Nasri et al., 2015). Combinations of the common medications used to treat or reduce the symptoms of T2DM with medicinal plants may increase the efficacy and safety of the treatments in synergistic manner.

According to traditional Indonesian medicine, Andrographis paniculata (Burm. f.) Wall. ex Nees (AP) is described as one among the prioritized medicinal plants and this herb is being used mainly for jamu pahitan, whose use is a part and parcel of Indonesian culture recognized internationally (Komalasari and Harimurti, 2015; Lanawati et al., 2012; Limyati and Juniar, 1998). The antidiabetic effects of $A$. paniculata have been investigated by number of researchers from in silico studies to human evidence (Kooti et al., 2016; Niranjan et al., 2010; Nizmawardini et al., 2013; Xu et al., 2007, 2010). It has also a wide range of pharmacological effects (Akhtar et al., 2016; Jayakumar et al., 2013; Rajasekaran et al., 2016), including hepatoprotective (Nasir et al., 2013; Vetriselvan and Middha, 2016), antioxidant (Dandu and Inamdar, 2009), and anti-inflammatory (Zou et al., 2016), which are beneficial for people with T2DM, since it may help minimize complications of diabetes. On the other hand, Syzygium polyanthum (Wight.) Walp (SP) or Indonesian bay leaves commonly used spices was assessed for antidiabetic activity in Indonesia (Anggowati and Sukrasno, 2004; Studiawan and Santosa, 2005; Wahyono and Susanti, 2008; Widyawati et al., 2015) with the beneficial effect of antioxidants (Lelono et al., 2009), and it has been reported to promote wound healing, which is seriously blunted in diabetes (Bowling et al., 2015; Sumono and Wulan, 2008).

In our previous study, AP and SP were selected for examination of their antidiabetic effects (Widharna et al., 2015). We found that the 6 : $1(\mathrm{w} / \mathrm{w})$ mixture of the two aqueous extracts showed antidiabetic effects with improvement of pancreatic islet cells in alloxan-induced diabetic male rats. In this work, we examined the effects of supplementation with metfomin alone and metformin combined with extract mixture (EM) at a dose $900 \mathrm{mg}$ /day on blood glucose, and other metabolic markers. The present work deals with the phytochemical analysis, identification of volatile compounds of the extracts and whether the extract mixture could complement the standard antidiabetic treatment with metformin and render added protection to patients with $\mathrm{T} 2 \mathrm{DM}$, in randomized placebo controlled, double-blinded parallel clinical trial.

\section{Methods}

\section{Extract mixture tablets}

The leaves of $A$. paniculata and $S$. polyanthum were collected from the area of Pandaan, East Java, Indonesia. The leaves were washed, rinsed, blotted, sliced and grounded. The phytochemical constituents were extracted in leaf/water ratio of $1: 4(\mathrm{~g} / \mathrm{ml})$ at $80{ }^{\circ} \mathrm{C}$ for $4 \mathrm{~h}$. The solvent was evaporated in vacuo $(50-60 \mathrm{mmHg})$ and the aqueous extracts were mixed with $10 \%$ maltodextrin. Subsequently, the drying process was carried out using spray-drying technology in PT. Natura Laboratoria Prima. The powder yield of aqueous extracts was dried to approximately $10 \%$ of its initial weight (Widharna et al., 2015). The extract mixture has been formulated into tablets having the best combination of antidiabetic potencies (Hendriati et al., 2011). All tablet formulations were prepared in the laboratory of the Faculty of Pharmacy, Widya Mandala Catholic University Surabaya, Indonesia.

\section{Phytochemical screening}

\section{Test for glycosides}

Sample was mixed with $2 \mathrm{ml}$ of water, followed by $0.2 \mathrm{ml}$ of $0.1 \mathrm{M}$ $\mathrm{HCl}$ to hydrolyze the glycosides. A control was maintained in the same manner, except that water was used instead of the acid. The mixture was kept boiling for $5 \mathrm{~min}$ in water bath. Finally, equal volume of Fehling A and Fehling B reagents were added while continuing to shake the mixture in the bath for $10 \mathrm{~min}$. A brick-red precipitate formed from the hydrolysis of glycosides indicated the presence of glucosides.

\section{Test for terpenoids (Salkwoski test)}

Ten mg was dissolved in $2 \mathrm{ml}$ of $\mathrm{CHCl}_{3}$ and evaporated to dryness. Concentrated sulphuric acid $(2 \mathrm{ml})$ was then added and heated for about $2 \mathrm{~min}$. Development of a greyish colour indicates the presence of terpenoids.

\section{Test for alkaloids (Dragendorff test)}

About $10 \mathrm{mg}$ of sample was warmed with $2 \%$ sulphuric acid for $2 \mathrm{~min}$. It was filtered and few drops of Dragendorff's reagent was added and observed for colour change. Positive test gives an orange red precipitate.

\section{Ammonium test for flavonoids}

A portion of sample was heated with $10 \mathrm{ml}$ of ethyl acetate in water bath for $3 \mathrm{~min}$. The mixture was filtered and $4 \mathrm{ml}$ of filtrate was shaken with $1 \mathrm{ml}$ of dilute ammonia solution. A yellow coloration was taken as a positive test for presence of flavonoid.

\section{Test for saponin}

Sample was mixed with $5 \mathrm{ml}$ of water in a test tube, warmed and shaken vigorously. The formation of stable foam indicated the presence of saponins.

\section{Test for tannin}

About $0.5 \mathrm{ml}$ of the sample was boiled in $10 \mathrm{ml}$ of water in a test tube and then filtered. Few drops of $0.1 \%$ ferric chloride were added. A brownish green or a blue-black coloration was taken as a positive test for presence of tannin. 


\section{TLC-analysis}

Standard solutions containing $7000 \mathrm{ppm}$ AP, SP and EM respectively were prepared in methanol and aquadest $(5: 1.5, \mathrm{v} / \mathrm{v})$. Ten $\mu \mathrm{L}$ of the samples were applied on a precoated silica gel F254 aluminium plate. The plate was developed in ethyl acetate : methanol $(3: 7, \mathrm{v} / \mathrm{v})$ and the developed plate was visualized and scanned under UV 254 and $366 \mathrm{~nm}$ by means of Camag TLC scanner 3 (densitometer).

\section{Gas chromatography/mass spectrometry (GC/MS) analysis}

The GC-MS instrument (Shimadzu GCMS-QP2010S, Japan) was utilized in this analysis. The aqueous extract of AP and SP were analyzed on capillary column (Agilent J\&W DB-1, $30 \mathrm{~m} \times 0.25 \mu \mathrm{m} \times 0.25 \mu \mathrm{m})$. The injector temperature was set at $310{ }^{\circ} \mathrm{C}$, column temperature program was set at $80{ }^{\circ} \mathrm{C}(0 \mathrm{~min})$ with an increasing rate of $10-300^{\circ} \mathrm{C}$ ( $\left.33 \mathrm{~min}\right)$. The carrier gas used was helium gas with a constant flow of $0.5 \mathrm{ml} / \mathrm{min}$. The ion source was electron ionization (EI) operating at $70 \mathrm{eV}$. The temperature of ion source was set as $250{ }^{\circ} \mathrm{C}$ and the interface temperature was $305{ }^{\circ} \mathrm{C}$ with its solvent cut-off time of $3.0 \mathrm{~min}$. The start time was set at $3.2 \mathrm{~min}$ and the end time was set at $60 \mathrm{~min}$. The compounds were identified by comparing the retention indices with those reported in the literature and by comparing their mass spectra with the Wiley GC/MS Library and NIST. Only the peaks with similarity index of $80 \%$ or above were selected.

\section{Clinical evaluation}

The research protocol was approved by the Medical Ethics Committee of Dr. Soetomo General Hospital in Surabaya. The study was registered under number: 162/Panke.KKE/VII/2012. Sixty six patients with T2DM who repeatedly visited the Indonesian Traditional Medicine Polyclinic of Dr. Soetomo General Hospital in Surabaya were enrolled in a randomized placebo controlled double-blinded single centre clinical trial. The following inclusion criteria were used to recruit the subjects with T2DM: (1) men or women diagnosed with diabetes at age $\geq 30$ years, (2) taking no other medicines such as steroid or weight loss drug that could influence blood glucose level (3) being not on any other hypoglycemic treatment for minimum two weeks before the study (4) willingness to follow the research protocol. Patients with type 1 diabetes, diabetes with complications, allergy to AP, SP, or metformin, chronic or acute hepatic disease, cardiovascular disease for minimum of 12 months before the study were excluded from the present study.

At first screening visit, patients were evaluated for eligibility criteria. After being informed about the details of the study orally and in printed matter, those who agreed to participate signed a free and informed consent form. Patients were randomized to the intervention group and the control group by randomly drawing lots previously defined by a non-participant of the study. On the next day all patients came after overnight fasting and after physical examination, blood was collected for biochemical examination including fasting blood glucose, postprandial glucose, haemoglobin A1c, triglycerides, total cholesterol, low density lipoprotein, high density lipoprotein, SGOT, SGPT, uric acid, creatinine, and BUN served as baseline values.

All patients took a single dose of $500 \mathrm{mg}$ twice a day of metformin tablets. In the intervention group, the patients received $450 \mathrm{mg}$ twice a day of EM tablets (Nair and Jacob, 2016), while in the control group the patients received a placebo tablet twice a day as well. Subsequently, patients were asked to attend the Indonesian Traditional Medicine Polyclinic of the Dr. Soetomo General Hospital in Surabaya in week 4 and week 8 after overnight fasting. The general physical and biochemical examination was performed at the first and the third visits to observe possible outcomes of extract mixture therapy in patients who were receiving metformin as a standard medical treatment of diabetes mellitus type 2 . At the second visit, only the biochemical examination was carried out, except HbA1c test. Both the clinical team and participants were blinded from the time of randomization until analysis was completed.

\section{Statistical analysis}

All data were expressed as mean \pm SD and a p-value less than 0.05 was considered statistically significant (Table 3 ). For categorical variables, the two groups were compared with contingency table analyses using chi-square statistics. A two-tailed $\tau$-test was used to compare groups for continuous variables,. The paired Student's $\tau$-test was used to compare the means of two variables for a single group. The sign test or Wilcoxon signed-rank test was used as an alternative to the paired Student's $\tau$-test for dependent samples when the variables cannot be assumed to be normally distributed.

\section{Results}

The aqueous extract of AP and SP, and extract mixture were subjected to phytochemical screening for the presence of glycosides, terpenoids, alkaloids, flavonoids, saponins, and tannins. The results of phytochemical analysis were given in Table 1. TLC photodocumentation of AP, SP and EM are shown in Fig. 1, while their Rf values of the spots and TLC densitometric scan at UV 254 and $366 \mathrm{~nm}$ were shown in Fig. 2. The GC-MS analysis of AP and SP showed the presence of 19 and 12 phytochemical compounds representing the total volatile fraction of AP (95.54\%) and SP (86.83\%) respectively (Fig. 3). The relative concentrations of the volatile components identified are presented in Table 2.

Sixty-six patients were fulfilled the selection criteria and agreed to sign the letter of informed consent. Twelve of these patients were lost during follow-up, whereas fifty-four patients were followed until the end of the study. Table 3 shows the general characteristics of the intervention group compared with the controls. At the baseline level, there was no significant difference between the two groups regarding age and gender. The mean of age of patients were $52.55 \pm 10.04$ (female 18, male 9) and $53.74 \pm 9.25$ (female 14, male 13) for the control and intervention groups, respectively.

EM and placebo supplementation had no effect on systolic and diastolic blood pressure, HbA1c, triglycerides, HDL-cholesterol, SGOT, GGT, creatinine, and BUN in Table 4. For more detailed information, see Supplementary Figs. S3 and S4. Total cholesterol and LDL cholesterol were significantly reduced in both groups.

The decrease in fasting blood glucose levels (FPG) was significant with extract mixture supplementation only for 4 weeks (visit 2), but after 8 weeks (visit 3 ) the treatment of the patients with extract mixture did not result any change in fasting blood glucose level compared to before the treatment, while the control groups had no change in fasting blood glucose level when compared to their baseline levels throughout the study (Table 4).

The body mass index (BMI) values were unchanged in the control group, while it decreased significantly in the intervention group (Table 4). Changes in BMI showed a decreasing trend but were

Table 1

Photochemical screening for the EM of $A$. paniculata and $S$. polyanthum leaves.

\begin{tabular}{lllll}
\hline No. & Phytochemicals & Ap & Sp & EM \\
\hline 1. & Glycosides & + & + & + \\
2. & Terpenoids & + & + & + \\
3. & Alkaloids & - & + & + \\
4. & Flavonoids & + & + & + \\
5. & Saponins & + & - & + \\
6. & Tannins & - & + & + \\
\hline
\end{tabular}




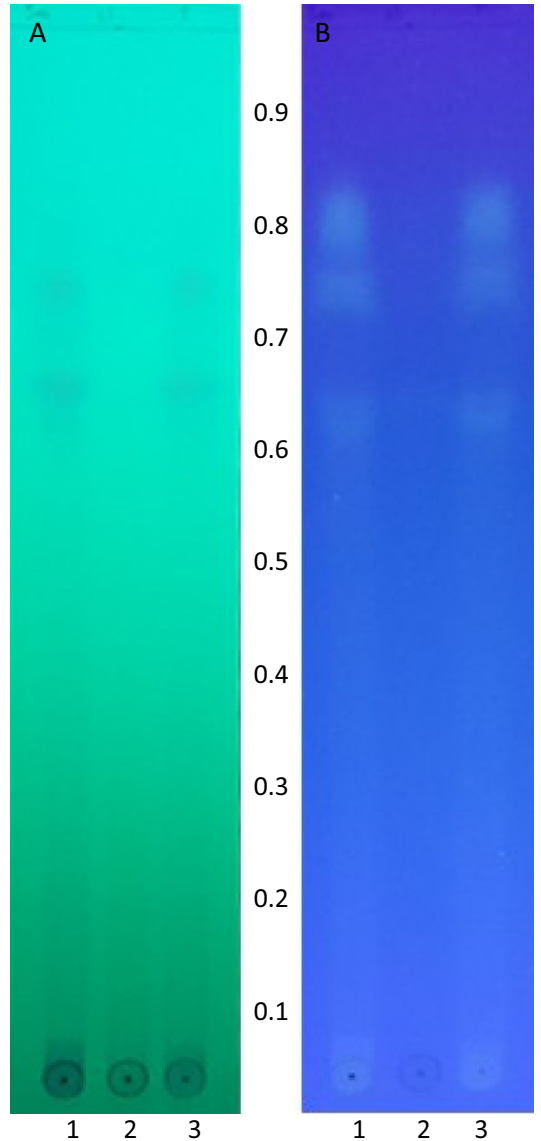

Fig. 1. TLC profile of AP (track 1), SP (track 2), and EM (track 3) at UV $254 \mathrm{~nm}$ (A) and $366 \mathrm{~nm}$ (B) on silica $60 \mathrm{~F} 254$ with solvent system ethyl acetate : methanol $(30: 70, \mathrm{v} / \mathrm{v})$.

statistically significant only in the intervention group. Before the treatment, most patients in both groups were overweight $\left(25 \leq \mathrm{BMI}<30 \mathrm{~kg} / \mathrm{m}^{2}\right.$ ), which were changes in BMI in the control and intervention group, respectively. Treatment of patients with the extract mixture for 8 weeks improved significantly the BMI values to normal weight.

Postprandrial glucose levels (PPG) showed a significant reduction compared to baseline levels in the intervention group, while the significant decrease of PPG in the control group could only be detected at visit 2 or 4 treatment weeks (Table 4). When compared to the control group, the decline in PPG was higher with extract mixture in subjects supplemented with the extract mixture, even though no significant difference was found between both groups. However, distribution of PPG before and after treatment indicated that the distribution for the intervention group shifted to the smaller value after treatment, while the distribution for the intervention group widened compared to the baseline values.

Liver function markers (SGOT and GGT) were unchanged with the extract mixture treatment for 56 days in type 2 diabetic patients in both groups (Table 4), while SGPT decreased significantly at the end of the study in the intervention group. Patients in the control group showed a significant increase in SGPT at visit 2 (4 treatment weeks), but it decreased to baseline values after treatments. On the contrary, the treatment with the extract mixture produced a significant decrease in SGPT.

As markers of renal function uric acid, creatinine and BUN levels were examined. When compared to the baseline levels, uric acid levels for the intervention group remained stable, while it increased significantly in the control group (Table 4). The other renal parameters were unchanged with extract mixture treatment for 56 days.

\section{Discussion}

A. paniculata (AP) is one of the most well-studied medicinal plant, with reports on its chemical constituents (Hossain et al., 2014; Sharma et al., 2012; Srivastava et al., 2004). On the other hand, S. polyanthum (SP), widely used as spices and traditional medicine in Indonesia and Malaysia, has received more attention in recent years and its phytochemical screening has been intensively investigated due to their potentially wider safety margin and useful pharmacological effects (Hassan et al., 2015; Kusuma et al., 2011; Rahim et al., 2018). The Indonesian Traditional Medicine Polyclinic of Dr. Soetomo General Hospital in Surabaya used extract mixture of AP-SP with ratio of 1:1 for T2DM treatment. The dose suggested was $1 \mathrm{~g}$ three times a day ( $3 \mathrm{~g}$ a day). In traditional use, herbal medicine comes mostly in form of herbal decoctions, which are the simplest forms of herbal preparation. Several studies have compared various pharmacological effects of aqueous and ethanolic extracts of herbal medicines, but there was no general conclusion which kind of extract had better activities (Hosseinzadeh et al., 2014; Hosseinzadeh et al., 2013; Ju and Kim, 2008; Singh, 2010). However, our previous work showed that there was no significant difference of hypoglycemic activity between aqueous and ethanolic extracts of Andrographolide paniculata on glucose tolerance test in rats (Hendriati et al., 2010). Moreover, we reported that the extract mixture of AP-SP with ratio of $6: 1$ was beneficial for pancreatic beta-cells (Widharna et al., 2015). The development of parameters for standardization in herbal medicine is a challenging task.

In this study, a phytochemical screening was performed for each extract and tablets of the extract mixture (EM). The results obtained for phytochemical analysis of AP, SP and EM indicate the presence of glycosides, terpenoids, flavonoids, and saponins in AP, while glycosides, terpenoids, alkaloids, flavonoids, and tannins were present in SP as detailed out in the Table 1. Various major groups of phytochemicals were detected to be present in EM and could be beneficial for diabetic patients (Rahimi-Madiseh et al., 2014). Moreover, in the TLC analysis, we reported that the best separation was achieved with mixture of ethyl acetate : methanol $(3: 7, \mathrm{v} / \mathrm{v})$ as a mobile phase. In Fig. 1 , the photo documentation of the plates showed several bands under UV 254 and $366 \mathrm{~nm}$. There were 2 spots under $254 \mathrm{~nm}$ and 3 spots under $366 \mathrm{~nm}$ for AP and EM, while no spot was observed for SP. However, densitometric scan of AP under 254, and $366 \mathrm{~nm} \mathrm{UV}$, revealed 6 and 5 peaks, respectively, of which $\mathrm{Rf} 0.70(22.55 \%)$ was recognized as major one for $254 \mathrm{~nm}$, and Rf 0.69 (30.18\%) as major one for $366 \mathrm{~nm}$ (Fig. 2: A1 and B1). On the other side, densitometric scan of SP under 254 and 366 $\mathrm{nm}$ showed the presence of 5 and 4 peaks, respectively, of which Rf $0.80(42.93 \%)$ was major one for $254 \mathrm{~nm}$ and Rf 0.76 was for $366 \mathrm{~nm}$ in Fig. 2 part A2 and B2. EM resolved into peaks at similar wavelengths to the ones of AP with a different area composition ratio (Fig. 2: A3 and B3). These changes may be attributed to AP:SP ratio of $6: 1$. The TLC analysis had been performed carefully with different developers (data not shown) and one of those gave the best separation we reported in this study. It was noted that there was one peak near the base band with the lowest $\mathrm{Rf}$ value indicated the high-polarity compounds. Further works, such as two-dimensional TLC analysis or LC-MS/MS, are clearly needed to better standardize the extracts.

Previous studies using GC-MS determined the chemical profile of chloroform extracts of the aerial part of AP (Roy et al., 2010), ethanol whole crude extract (Kumar and Gani, 2017), acetone leaf extract (Thangavel et al., 2015), ethanol leaf extract (Udobre et al., 2016; Vasantha et al., 2013), and methanol leaf extract (Krishnamoorthy and Kalaiselvan, 2016; Panda and Bandyopadhyay, 2013; Shalini and Narayanan, 2015). Besides, the GC-MS analysis of n-hexane, ethyl acetate, and methanol leaf extract of SP has been has been reported (Rahim et al., 2018). However, the differences between the previous results and our present finding could be due to the origin of the plants and the different types of extraction. In the present study, the GC-Ms analysis showed that the aqueous extract of AP had more compounds 

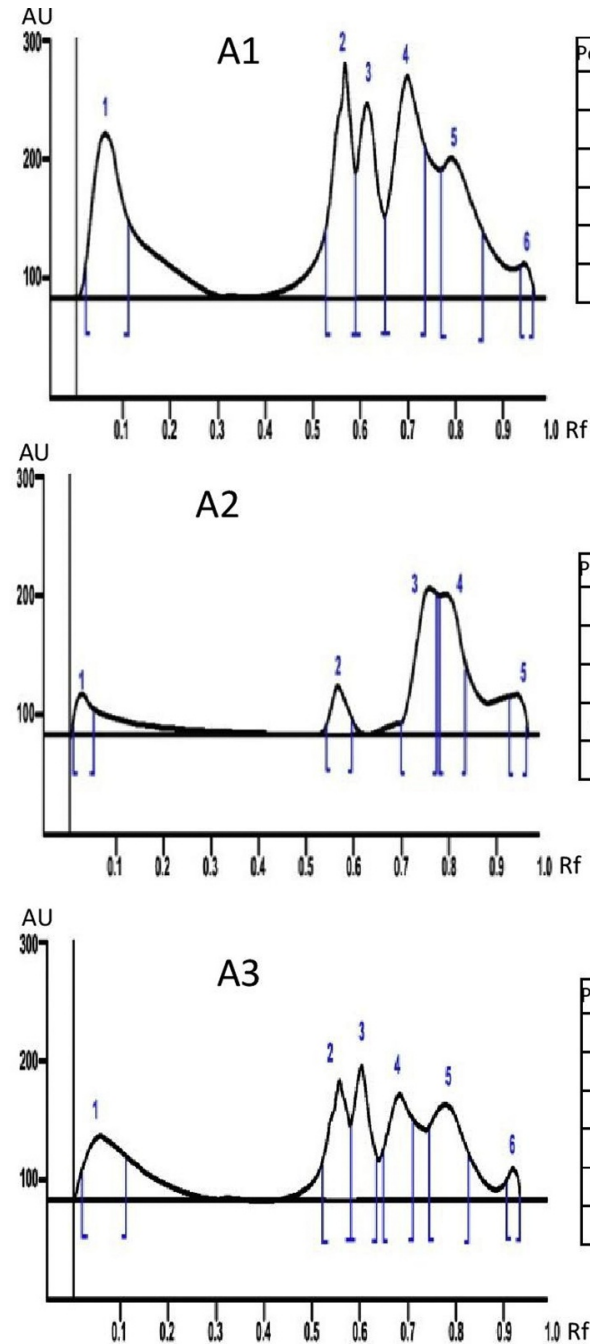

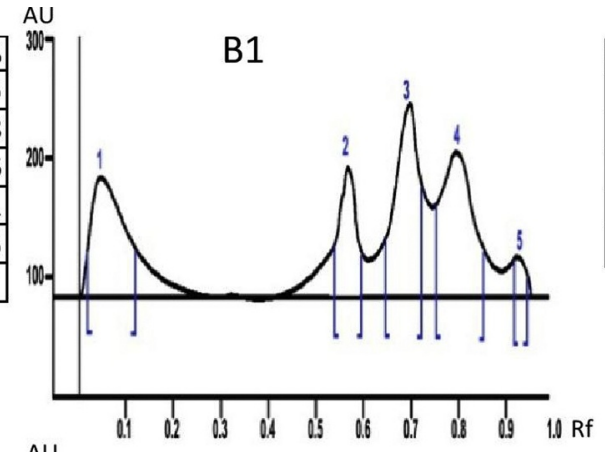

\begin{tabular}{|c|r|r|}
\hline eak & Max Rf & Area \% \\
\hline 1 & 0.04 & 24.06 \\
\hline 2 & 0.58 & 17.41 \\
\hline 3 & 0.69 & 30.18 \\
\hline 4 & 0.79 & 27.56 \\
\hline 5 & 0.91 & 0.78 \\
\hline
\end{tabular}

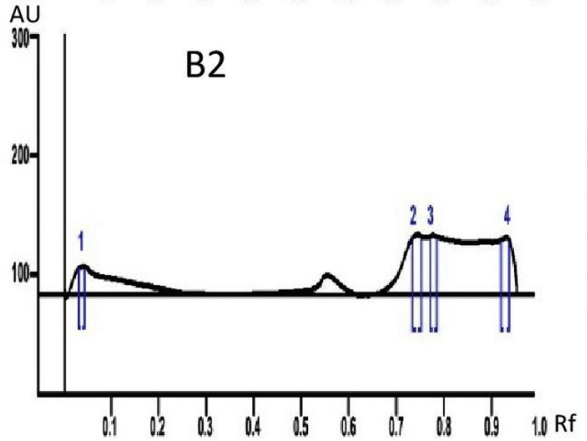

\begin{tabular}{|c|c|c|}
\hline eak & Max Rfferea \% \\
\hline 1 & 0.02 & 17.87 \\
\hline 2 & 0.76 & 36.80 \\
\hline 3 & 0.79 & 18.76 \\
\hline 4 & 0.93 & 26.57 \\
\hline
\end{tabular}

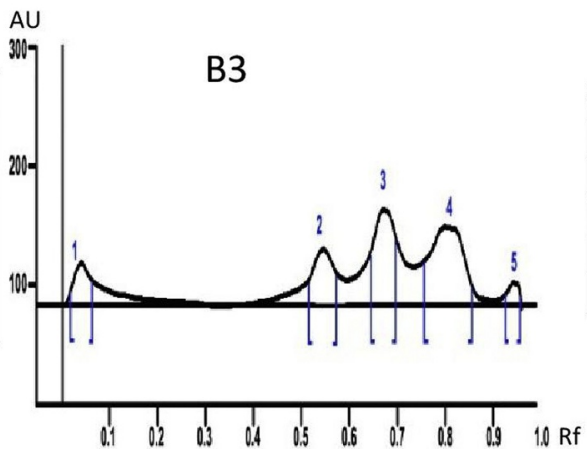

Fig. 2. TLC Densitometric scan of AP (1), SP (2), and EM (3) at UV $254 \mathrm{~nm}$ (A) and $366 \mathrm{~nm}$ (B).

than the aqueous extract of SP. The aqueous AP extract had nineteen peaks whereas aqueous SP extract had twelve major peaks. The common compounds in each extract were: peaks $2,5,8,15,17,20,21$, and 22 with RT 16.22, 18.36, 18.76, 20.86, 21.12, 22.81, 22.90, and 23.16 for AP and peaks $3,8,12,14,15,17,18$, and 19 with RT 16.22 , $18.35,18.77,20.87,21.12,22.82,22.90$, and 23.16 for SP, which were $86 \%$ and $82 \%$ of total volatile fraction for AP and SP respectively. Fatty acids and esters (AP: 74. 57\%, SP: 62.82\%) were found to be the highest constituents in the crude extract followed by terpenoids (AP: $11.16 \%$, SP: $12.30 \%$ ) and hydrocarbons (AP: 6.19\%, SP: 9.87\%). The most abundant compound were the esters 9-octadecenoic acid, methyl ester (AP: $26.65 \%$, SP: $27.07 \%$ ) and eicosanoic acid, methyl ester (AP: $24.47 \%$, SP: $17.23 \%)$.

The reliability of the usage of medicinal plants is correlated with the phytochemical compounds Some compounds were shown to possess important biological activities. For instance, 9-octadecenoic acid (Z)-, methyl ester, the highest content of the extracts has anti-inflammatory, antiandrogenic, and anemiagenic properties (Surender et al., 2008). The other compound, eicosanoic acid, methyl ester, the second highest content of both extracts showed $\alpha$-glucosidase inhibitor activity (Artanti et al., 2012). Caryophyllene oxide, a bicyclic sesquiterpene, showed strong anti-cancer effects against MG-63 human osteosarcoma cells through suppression of cancer cell migration tendency and induction of apoptosis (Pan et al., 2016). Furthermore, 9,12-octadecadienoic acid (Z,Z)-, methyl ester or methyl linoleate used as a flavouring ingredient possesses antifungal and antioxidant activities. All the major compounds identified in the present analysis were obviously different with the major ones in the previous studies mentioned earlier. These findings suggested the beneficial effects of the extracts and that the antidiabetic activities of the aqueous leaf extracts of AP and SP might be related to the presence of eicosanoic acid, methyl ester. Moreover, in order to analyze andrographolide in AP, and apigenin and quercetin in SP, an HPLC method was employed. This approach was not successful in separating the compounds in the extracts due to insufficient column selectivity and efficiency. The HPLC results can be find in Supplementary Materials (Figs. S1 and S2).

Potencies of AP and SP leaves against different ailments have been evaluated by numerous studies (Kusuma et al., 2011; Rajasekaran et al., 2016; Sundari, 2010; Widyawati et al., 2015). However, clinical trials investigating their antidiabetic effects are still limited. Agarwal et al. (2005) reported that treatment with dry powder of aerial part of AP starting with $600 \mathrm{mg}$, gradually increasing to a maximum of $1.8 \mathrm{~g} /$ day for 12 weeks, resulted a significant fall in HbA1c and fasting serum insulin and did not induce significant adverse events on 20 patients with type 2 diabetes mellitus. Another study has been done by Nizmawardini et al. using metformin and dry extract of $A$. paniculata leaves with dosage $1.54 \mathrm{~g}$ /day for 14 days in 34 diabetic patients showed some effects on PPG (Nizmawardini et al., 2013). However, the study was quite short in duration and it lacked information about the impact of the extract on organs involved in detoxification. The only one clinical trial that involved applying both extracts AP and SP (1:1) 2.1 g/day with metformin $500 \mathrm{mg} /$ day on 30 diabetic patients was 

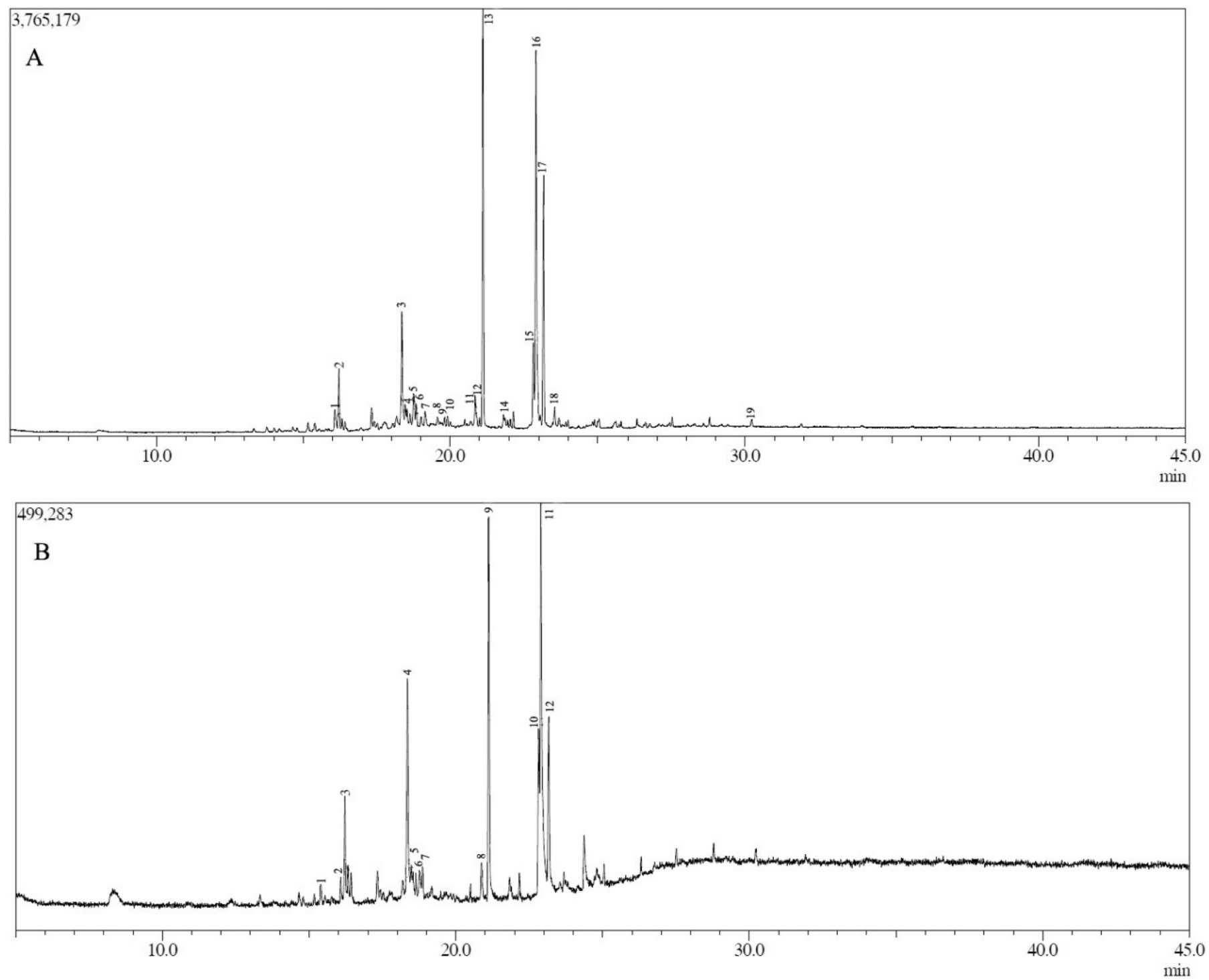

Fig. 3. GC-MS Chromatogram of A. paniculata (A) and S. polyanthum (B).

conducted by Suharmiati and Roosihermiatie (2012). The results showed a significant reduction in FPG levels compared to FPG levels before treatment and no adverse effects of high dose extracts after 4 weeks of treatments on 15 diabetic patients intervention group, while the FPG levels in the control group were changed not significantly. Nevertheless, there was no scientific evidence available indicating that an extract ratio of $1: 1$ was the most favourable ratio for diabetic patient. Based on our previous study, we found that the extract ratio of 6 : 1 (AP:SP) potently restored pancreatic islet cells of Wistar rats compared to the other ratios (Widharna et al., 2015). Therefore, the study reported here was designed to evaluate the safety and efficacy of the extract ratio of $6: 1$ (AP:SP) supplementation for diabetic patients with a larger sample size and a longer time of therapy compared to previous studies. This had the advantage of better results in the safety and efficacy analysis of the extract mixture in diabetic patients (Fig. 4).

Metformin is one of two classes oral antidiabetic agents that has not been related with weight gain (Golay, 2008). It may help people with diabetes to lose weight by reducing food intake (Lee and Morley, 1998; Paolisso et al., 1998). It is clearly important to avoid unnecessary weight gain for diabetic patients, particularly patients who are already overweight or obese. In the present work, the intervention group revealed a significant improvement of mean body mass index compared to the control group (Table 3). This observation is interesting since it means that we may combine other antidiabetic agents, especially, that can increase body weight such as insulin secretagogues or insulin itself, with the EM for treating T2DM (Fig. 5).

Data concerning interaction of AP with some conventional drugs like naproxen with synergetic effect (Balap et al., 2017), theophylline and midazolam (Jutiviboonsuk, 2015) have been reported. Although interaction data of AP with antidiabetic drug have not been reported (Gupta et al., 2017), AP has been shown to inhibit CYP2C19 activity (Jutiviboonsuk, 2015; Pan et al., 2011). Therefore, AP has the potential to interact with some antidiabetic drug such as glibenclamide and glimepiride, but not with metformin. On the other hand, there was no information about drug interaction of SP but based on its daily used in Indonesian cuisine, we can expect that it is most probably safe taken with metformin. A suggested dose of the Indonesian Traditional Medicine Polyclinic, Dr. Soetomo General Hospital in Surabaya was $3 \mathrm{~g}$ per day as mentioned earlier.

One of the central issues in the treatment of patients with type 2 diabetes is achieving glycemic control to prevent the microvascular and macrovascular complications of diabetes. Control of plasma glucose in diabetic patients can be evaluated by measuring glycated haemoglobin (HbA1c), fasting plasma glucose (FPG), and postprandial glucose (PPG). An overall picture of average blood glucose levels over the past two to three months can be provided by measuring glycated haemoglobin 
Table 2

Phytochemical compounds identified in leaf aqueous extracts of $A$. paniculata and $S$. polyanthum by GC-MS.

\begin{tabular}{|c|c|c|c|c|c|c|}
\hline \multirow[t]{2}{*}{ Compounds } & \multirow[t]{2}{*}{ Formula } & \multirow[t]{2}{*}{ Mass } & \multicolumn{2}{|l|}{ Area $\%$} & \multicolumn{2}{|l|}{ RT/line } \\
\hline & & & $\mathrm{AP}$ & SP & $\mathrm{AP}$ & SP \\
\hline Fatty acids and esters & & & 74.57 & 62.82 & & \\
\hline Decanoic acid, methyl ester & $\mathrm{C}_{11} \mathrm{H}_{22} \mathrm{O}_{2}$ & 186 & 0.93 & & $18.85 / 9$ & \\
\hline Nonanoic acid, methyl ester & $\mathrm{C}_{10} \mathrm{H}_{20} \mathrm{O}_{2}$ & 172 & & 1.48 & & $18.86 / 13$ \\
\hline Eicosanoic acid, methyl ester & $\mathrm{C}_{21} \mathrm{H}_{42} \mathrm{O}_{2}$ & 326 & 24.47 & 17.23 & $21.13 / 17$ & $21.12 / 15$ \\
\hline Hexadecanoic acid, ethyl ester & $\mathrm{C}_{18} \mathrm{H}_{36} \mathrm{O}_{2}$ & 284 & 1.96 & & $21.82 / 18$ & \\
\hline 9,12-Octadecadienoic acid (Z,Z)-, methyl ester & $\mathrm{C}_{19} \mathrm{H}_{34} \mathrm{O}_{2}$ & 294 & 4.99 & 7.96 & $22.81 / 20$ & $22.82 / 17$ \\
\hline 9-Octadecenoic acid, methyl ester & $\mathrm{C}_{19} \mathrm{H}_{36} \mathrm{O}_{2}$ & 296 & 26.65 & 27.07 & $22.90 / 21$ & $22.90 / 18$ \\
\hline Tricosanoic acid & $\mathrm{C}_{24} \mathrm{H}_{48} \mathrm{O}_{2}$ & 368 & 14.58 & 9.08 & $23.16 / 22$ & $23.16 / 19$ \\
\hline Ethyl octadec-9-enoate & $\mathrm{C}_{20} \mathrm{H}_{38} \mathrm{O}_{2}$ & 310 & 0.99 & & $23.53 / 23$ & \\
\hline Terpenoids & & & 11.16 & 12.30 & & \\
\hline Guaiol & $\mathrm{C}_{15} \mathrm{H}_{26} \mathrm{O}$ & 222 & 1.68 & & $16.07 / 1$ & \\
\hline (-)-Caryophyllene oxide & $\mathrm{C}_{15} \mathrm{H}_{24} \mathrm{O}$ & 220 & 7.86 & 12.3 & $18.36 / 5$ & $18.35 / 8$ \\
\hline Dihydrocarvyl acetate & $\mathrm{C}_{12} \mathrm{H}_{20} \mathrm{O}_{2}$ & 196 & 1.02 & & $19.15 / 11$ & \\
\hline$\alpha$-Limonene diepoxide & $\mathrm{C}_{10} \mathrm{H}_{16} \mathrm{O}_{2}$ & 168 & 0.6 & & $19.57 / 12$ & \\
\hline Hydrocarbons & & & 6.19 & 9.87 & & \\
\hline Cyclopropane, 1-(2-methylene-3-butenyl)-1-(1-methylenepropyl)- & $\mathrm{C}_{12} \mathrm{H}_{18}$ & 162 & & 1 & & $15.4 / 1$ \\
\hline 1-Tridecene & $\mathrm{C}_{13} \mathrm{H}_{26}$ & 182 & & 1.18 & & $16.083 / 2$ \\
\hline Tetradecane & $\mathrm{C}_{14} \mathrm{H}_{30}$ & 198 & 3.34 & 4.94 & $16.22 / 2$ & $16.217 / 3$ \\
\hline 1-Decene & $\mathrm{C}_{10} \mathrm{H}_{20}$ & 140 & & 1.44 & & $18.475 / 9$ \\
\hline 1-Hexadecene & $\mathrm{C}_{16} \mathrm{H}_{32}$ & 224 & 0.63 & & $18.47 / 6$ & \\
\hline Hexadecane & $\mathrm{C}_{16} \mathrm{H}_{34}$ & 226 & 1.9 & 1.31 & $18.76 / 8$ & $18.767 / 12$ \\
\hline 1-Tetradecene & $\mathrm{C}_{14} \mathrm{H}_{28}$ & 196 & 0.32 & & $19.81 / 13$ & \\
\hline Eicosane & $\mathrm{C}_{20} \mathrm{H}_{42}$ & 282 & 0.41 & & $21.01 / 16$ & \\
\hline Ketones & & & 2.17 & 1.84 & & \\
\hline 2-Pentadecanone & $\mathrm{C}_{15} \mathrm{H}_{30} \mathrm{O}$ & 226 & 2.17 & 1.84 & $20.86 / 15$ & $20.875 / 14$ \\
\hline Others & & & 1.04 & 0 & & \\
\hline Myristyl chloride & $\mathrm{C}_{14} \mathrm{H}_{29} \mathrm{Cl}$ & 232 & 0.57 & & $19.92 / 14$ & \\
\hline Silicate anion tetramer & $\mathrm{C}_{24} \mathrm{H}_{72} \mathrm{O}_{12} \mathrm{Si}_{12}$ & 888 & 0.47 & & $28.79 / 26$ & \\
\hline
\end{tabular}

Table 3

Demographic characteristics of patients in control and intervention group.

\begin{tabular}{llll}
\hline & Control group & Intervention group & $P$ value \\
\hline Age (year) & $52.55 \pm 10.04$ & $53.74 \pm 9.25$ & 0.986 \\
Sex (female/male) & $18 / 9$ & $14 / 13$ & 0.268
\end{tabular}

(HbA1c). If HbA1c test is not available, postprandial and fasting plasma glucose can be estimated to assess glycemic control. Based on our results (Table 3), there were trends towards a decrease, but no significant changes were observed in FPG and HbA1c with the EM supplementation, while a significant decrease in PPG was observed in the intervention group. It should be noted that even after treatment for 56 days, the FPG had not fallen to normal values; this is probably because the dose is not high enough. However, treatment with metformin and the extract mixture produced a significant decrease in postprandial glucose levels within eight weeks. The relationship between PPG and HbA1c has been studied extensively and some found that PPG strongly correlated with $\mathrm{HbA1c}$ or contributes significantly to overall glycemic control (Ketema and Kibret, 2015). The results suggested that the EM improves glycemic in the type 2 diabetic patients.

A significant increase in SGPT at visit 2 in the control group was in accordance with the findings of hepatoxicity of metformin (BernalLopez et al., 2012; Vagula and Devi, 2008). However, metformin-induced hepatotoxicity is very rare and only few cases have been reported in the literature (Aksay et al., 2007; Babich et al., 1998; Deutsch et al., 2004; Zheng, 2016). The results of the current study showed that the SGPT levels were unchanged in the intervention group, while there was a significant increase at visit 2 in the control group indicated that extract mixture may mitigate the hepatotoxic effect or even could fortify liver against this effect. Our results are in good agreement with previous investigations for indicating the hepatoprotective activity of aqueous and methanolic extracts of A. paniculata (Sutha et al., 2010; Trivedi and Rawal, 2001).

Another serious but rare side effect of metformin is lactic acidosis because of its inference with mitochondrial oxidative processes. While metformin-induced hepatotoxicity has been rarely reported, metfominassociated metabolic acidosis is a widely recognized side effect of this drug (DeFronzo et al., 2015). Metformin is contraindicated in many type 2 diabetic patients with impaired renal function because of consideration of lactic acidosis (Inzucchi et al., 2014). Impaired renal function can result in increase of uric acid, creatinine, and BUN levels. Furthermore, metabolite syndrome such as diabetes is one of several factors associated as cause and consequences of high uric acid concentration. Our results showed that the uric acid level in the intervention group compared to baseline values had no change, while it increased significantly in the control group. This may indicate the ability of the extract mixture to provide some degree of protection to the kidney. The renoprotective of the extract mixture treated type 2 diabetic patients is in accordance with that observed by Singh et al. (2009).

\section{Conclusion}

In the present study, the extract mixture showed the presence of bioactive compound such as glycosides, terpenoids, alkaloids, flavonoids, saponins, and tannins. Our GC and GC-MS study of the aqueous leaf extracts of $A$. paniculata and $S$. polyanthum revealed the presence of major compounds such as 9-octadecenoic acid (Z)-, methyl ester, eicosanoic acid, methyl ester, and caryophyllene oxide with therapeutic importance. The main constituents were fatty acids and ester, terpenoids and hydrocarbons that justify the traditional usage of the plants. This study also leads to the further research in the way of isolation and identification of the active compound from the A. paniculata and $S$. polyanthum using extraction, chromatographic and spectroscopic techniques.

Our data showed that the combination of the extract mixture at a dose of $900 \mathrm{mg} /$ day with the standard treatment of metformin at a dose of $1000 \mathrm{mg} /$ day had an effect in lowering postprandrial glucose levels, along with major improvements in other metabolic parameters in 
Table 4

Clinical characteristic changes of patients in placebo and intervention group during 56 treatment days.

\begin{tabular}{|c|c|c|c|c|}
\hline & Control group & $p$ value & Intervention group & $p$ value \\
\hline \multicolumn{5}{|c|}{ BMI $\left(\mathrm{kg} / \mathrm{m}^{2}\right)$} \\
\hline Visit 1 & $26.60 \pm 0.84$ & \multirow[t]{2}{*}{$0.305^{1,3}$} & $26.28 \pm 0.74$ & \multirow[t]{2}{*}{$0.031^{* 1,3}$} \\
\hline Visit 3 & $26.37 \pm 0.91$ & & $25.93 \pm 0.69$ & \\
\hline \multicolumn{5}{|c|}{ Systolic blood pressure (mmHg) } \\
\hline Visit 1 & $137.04 \pm 5.16$ & \multirow[t]{2}{*}{$0.071^{1,3}$} & $132.11 \pm 3.95$ & \multirow[t]{2}{*}{$0.424^{1,3}$} \\
\hline Visit 3 & $128.89 \pm 3.61$ & & $129.07 \pm 3.39$ & \\
\hline \multicolumn{5}{|c|}{ Diastolic blood pressure (mmHg) } \\
\hline Visit 1 & $81.67 \pm 1.77$ & \multirow[t]{2}{*}{$0.847^{1,3}$} & $80.11 \pm 1.52$ & \multirow[t]{2}{*}{$0.362^{1,3}$} \\
\hline Visit 3 & $81.30 \pm 1.76$ & & $78.52 \pm 1.43$ & \\
\hline \multicolumn{5}{|c|}{ HbA1c (\%) } \\
\hline Visit 1 & $8.60 \pm 0.18$ & \multirow[t]{2}{*}{$0.238^{1,3}$} & $8.32 \pm 0.20$ & \multirow[t]{2}{*}{$0.715^{1,3}$} \\
\hline Visit 3 & $8.28 \pm 0.22$ & & $8.25 \pm 0.22$ & \\
\hline \multicolumn{5}{|c|}{ FPG (mg/dl) } \\
\hline Visit 1 & $212.04 \pm 11.62$ & $0.145^{1,2}$ & $198.70 \pm 11.02$ & $0.043^{* 1,2}$ \\
\hline Visit 2 & $188.67 \pm 12.32$ & $0.640^{2,3}$ & $173.63 \pm 12.68$ & $0.217^{2,3}$ \\
\hline Visit 3 & $193.00 \pm 11.35$ & $0.233^{3,1}$ & $183.93 \pm 12.54$ & $0.158^{3,1}$ \\
\hline \multicolumn{5}{|c|}{ PPG (mg/dl) } \\
\hline Visit 1 & $302.78 \pm 14.67$ & $0.024 * 1,2$ & $298.18 \pm 15.00$ & $0.002^{* 1,2}$ \\
\hline Visit 2 & $263.26 \pm 15.84$ & $0.849^{2,3}$ & $241.26 \pm 14.63$ & $0.851^{2,3}$ \\
\hline Visit 3 & $266.18 \pm 16.17$ & $0.053^{3,1}$ & $244.00 \pm 16.93$ & $0.017^{\star 3,1}$ \\
\hline \multicolumn{5}{|c|}{ Total cholesterol (mg/dl) } \\
\hline Visit 1 & $230.04 \pm 7.52$ & $0.006^{* 1,2}$ & $212.70 \pm 9.36$ & $0.048^{* 1,2}$ \\
\hline Visit 2 & $212.15 \pm 6.23$ & $0.833^{2,3}$ & $193.11 \pm 9.81$ & $0.382^{2,3}$ \\
\hline Visit 3 & $213.37 \pm 7.16$ & $0.002^{* 3,1}$ & $199.59 \pm 7.64$ & $0.040^{\star 3,1}$ \\
\hline \multicolumn{5}{|c|}{ Triglyceride (mg/dl) } \\
\hline Visit 1 & $148.89 \pm 13.90$ & $0.329^{1,2}$ & $146.74 \pm 17.25$ & $0.853^{1,2}$ \\
\hline Visit 2 & $141.52 \pm 12.56$ & $0.540^{2,3}$ & $145.22 \pm 20.74$ & $0.773^{2,3}$ \\
\hline Visit 3 & $136.00 \pm 10.80$ & $0.191^{3,1}$ & $148.33 \pm 15.53$ & $0.864^{3,1}$ \\
\hline HDL-chol & ol (mg/dl) & & & \\
\hline Visit 1 & $55.67 \pm 2.35$ & $0.880^{1,2}$ & $54.07 \pm 2.50$ & $0.353^{1,2}$ \\
\hline Visit 2 & $55.37 \pm 2.17$ & $0.076^{2,3}$ & $55.89 \pm 2.97$ & $0.459^{2,3}$ \\
\hline Visit 3 & $59.56 \pm 2.64$ & $0.066^{3,1}$ & $54.85 \pm 2.75$ & $0.618^{3,1}$ \\
\hline LDL-chol & ol (mg/dl) & & & \\
\hline Visit 1 & $144.18 \pm 6.51$ & $0.005^{\star 1,2}$ & $128.96 \pm 7.56$ & $0.020^{* 1,2}$ \\
\hline Visit 2 & $127.37 \pm 5.65$ & $0.836^{2,3}$ & $111.59 \pm 6.99$ & $0.562^{2,3}$ \\
\hline Visit 3 & $126.30 \pm 5.75$ & $0.001^{* 3,1}$ & $114.81 \pm 6.09$ & $0.037^{* 3,1}$ \\
\hline SGOT (IU & & & & \\
\hline Visit 1 & $20.22 \pm 1.78$ & $0.928^{1,2}$ & $21.74 \pm 1.78$ & $0.885^{1,2}$ \\
\hline Visit 2 & $20.07 \pm 1.85$ & $0.692^{2,3}$ & $21.48 \pm 1.44$ & $0.616^{2,3}$ \\
\hline Visit 3 & $20.74 \pm 1.87$ & $0.741^{3,1}$ & $20.74 \pm 1.60$ & $0.532^{3,1}$ \\
\hline SGPT (IU & & & & \\
\hline Visit 1 & $20.48 \pm 1.78$ & $0.011^{* 1,2}$ & $23.93 \pm 1.81$ & $0.561^{1,2}$ \\
\hline Visit 2 & $23.52 \pm 1.99$ & $0.109^{2,3}$ & $22.89 \pm 1.65$ & $0.260^{2,3}$ \\
\hline Visit 3 & $20.81 \pm 2.03$ & $0.840^{3,1}$ & $20.52 \pm 1.62$ & $0.050^{3,1}$ \\
\hline GGT (IU/ & & & & \\
\hline Visit 1 & $32.74 \pm 5.90$ & $0.551^{1,2}$ & $39.48 \pm 7.41$ & $0.579^{1,2}$ \\
\hline Visit 2 & $31.11 \pm 5.06$ & $0.903^{2,3}$ & $37.26 \pm 8.54$ & $0.400^{2,3}$ \\
\hline Visit 3 & $30.67 \pm 7.09$ & $0.495^{3,1}$ & $34.59 \pm 6.35$ & $0.194^{3,1}$ \\
\hline Uric acid & /dl) & & & \\
\hline Visit 1 & $4.19 \pm 0.28$ & $0.020^{* 1,2}$ & $4.92 \pm 0.34$ & $0.250^{1,2}$ \\
\hline Visit 2 & $4.91 \pm 0.31$ & $0.440^{2,3}$ & $5.42 \pm 0.34$ & $0.700^{2,3}$ \\
\hline Visit 3 & $5.08 \pm 0.28$ & $0.000^{* 3,1}$ & $5.44 \pm 0.36$ & $0.250^{3,1}$ \\
\hline Creatinin & $\mathrm{g} / \mathrm{dl})$ & & & \\
\hline Visit 1 & $0.92 \pm 0.05$ & $0.546^{1,2}$ & $1.13 \pm 0.09$ & $0.991^{1,2}$ \\
\hline Visit 2 & $0.94 \pm 0.05$ & $0.675^{2,3}$ & $1.13 \pm 0.11$ & $0.930^{2,3}$ \\
\hline Visit 3 & $0.95 \pm 0.06$ & $0.352^{3,1}$ & $1.13 \pm 0.10$ & $0.913^{3,1}$ \\
\hline BUN (mg & & & & \\
\hline Visit 1 & $11.81 \pm 0.61$ & $0.791^{1,2}$ & $12.15 \pm 0.83$ & $0.889^{1,2}$ \\
\hline Visit 2 & $12.02 \pm 0.82$ & $0.281^{2,3}$ & $12.27 \pm 1.21$ & $0.689^{2,3}$ \\
\hline Visit 3 & $11.18 \pm 0.44$ & $0.340^{3,1}$ & $11.85 \pm 0.76$ & $0.758^{3,1}$ \\
\hline
\end{tabular}

* Significant change; ${ }^{1,2}$ is the $p$ values from comparison of parameters at visit 1 and $2 ;{ }^{2,3}$ is the $p$ values from comparison of parameters at visit 1 and 2 ; ${ }^{3,1}$ is the $p$ values from comparison of parameters at visit 1 and 3; Visit 1, 2, and 3 are the measurements on day 1 or before treatments, at day 28 or week 4 , and at day 56 or week 8 , respectively.

humans with type 2 diabetes mellitus. Moreover, the extract mixture may assist in ameliorating weight gain associated with other antidiabetic agents. The present study also clearly indicated the hepatoprotective and renoprotective effects of $A$. paniculata. The combination of the extract mixture with metformin for the management of type 2

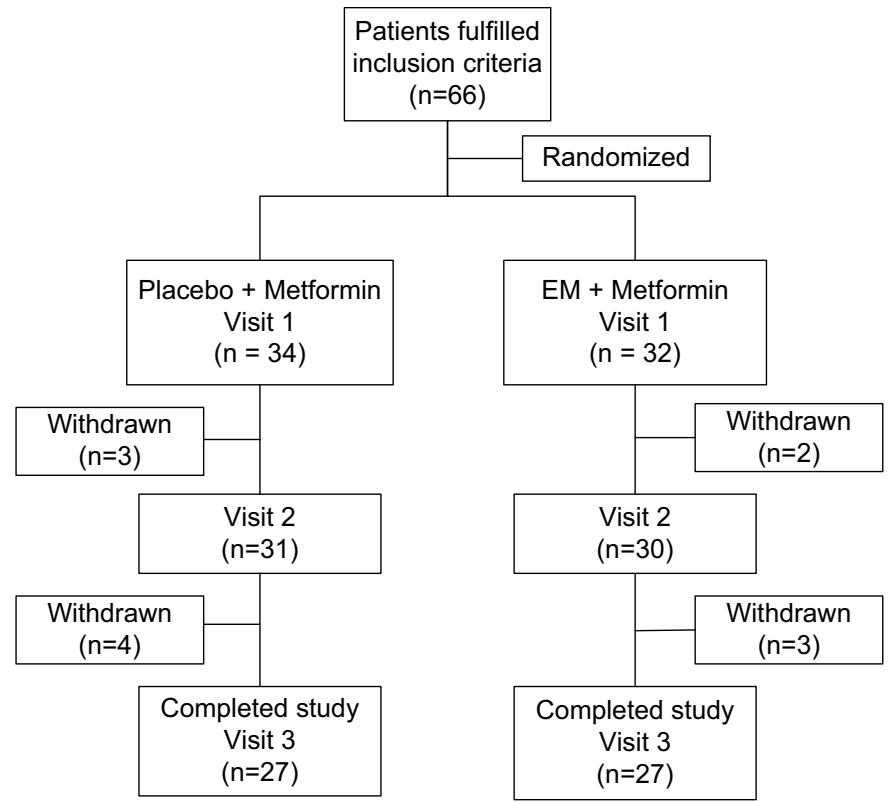

Fig. 4. CONSORT follow chart of the clinical study.

diabetes is highly encouraged with a reduction in the dose of metformin and an increase in the dose of the extract mixture (to guarantee efficacy and safety).

To conclude, it was understood from the present study that the extract of AP and SP contained many phytochemicals as revealed by phytochemical studies, TLC and GC-MS analysis. The results of our current study of 54 diabetic patients revealed the potential of the extract mixture of $A$. paniculata and $S$. polyanthum leaves in the treatment of type 2 diabetes mellitus in patients receiving metformin. Combination of metformin with the extract mixture is a promising therapeutic option for not only improving glycemic control but also being beneficial for liver and kidney which can be harmed by metformin on rare occasion.

\section{Limitation}

The TLC and GC-MS analysis were the first step towards understanding the nature of active compounds. Certainly, further studies are warranted to standardize the extract mixture, especially non-volatile compounds.

Despite providing a benefit, the current clinical study lacks sample size calculation and as a result has a low sample size, since this is the first report of the clinical use of aqueous extract mixture of AP and SP. We may commit type 2 error due to the absence of prior sample size calculation and the small sample size may lead to high chance of insufficient power to detect real effects is particularly troubling, where we fail to detect a difference where actually there is a difference. We should be cautious with the fact that there is no statistical significance doesn't mean the treatment failed. The study had a relatively short 8week duration and a low dose of the extract mixture $(900 \mathrm{mg} /$ day). A larger patient sample size, a higher dose and a longer duration, therefore, will be needed to validate our findings.

\section{Conflict of interest}

Authors report no financial or nonfinancial conflict of interests.

\section{Authors' contribution}

Elisabeth Catherina Widjajakusuma, Arijanto Jonosewojo and Adrianta Surjadhana originated the idea for this human trial. Elisabeth 


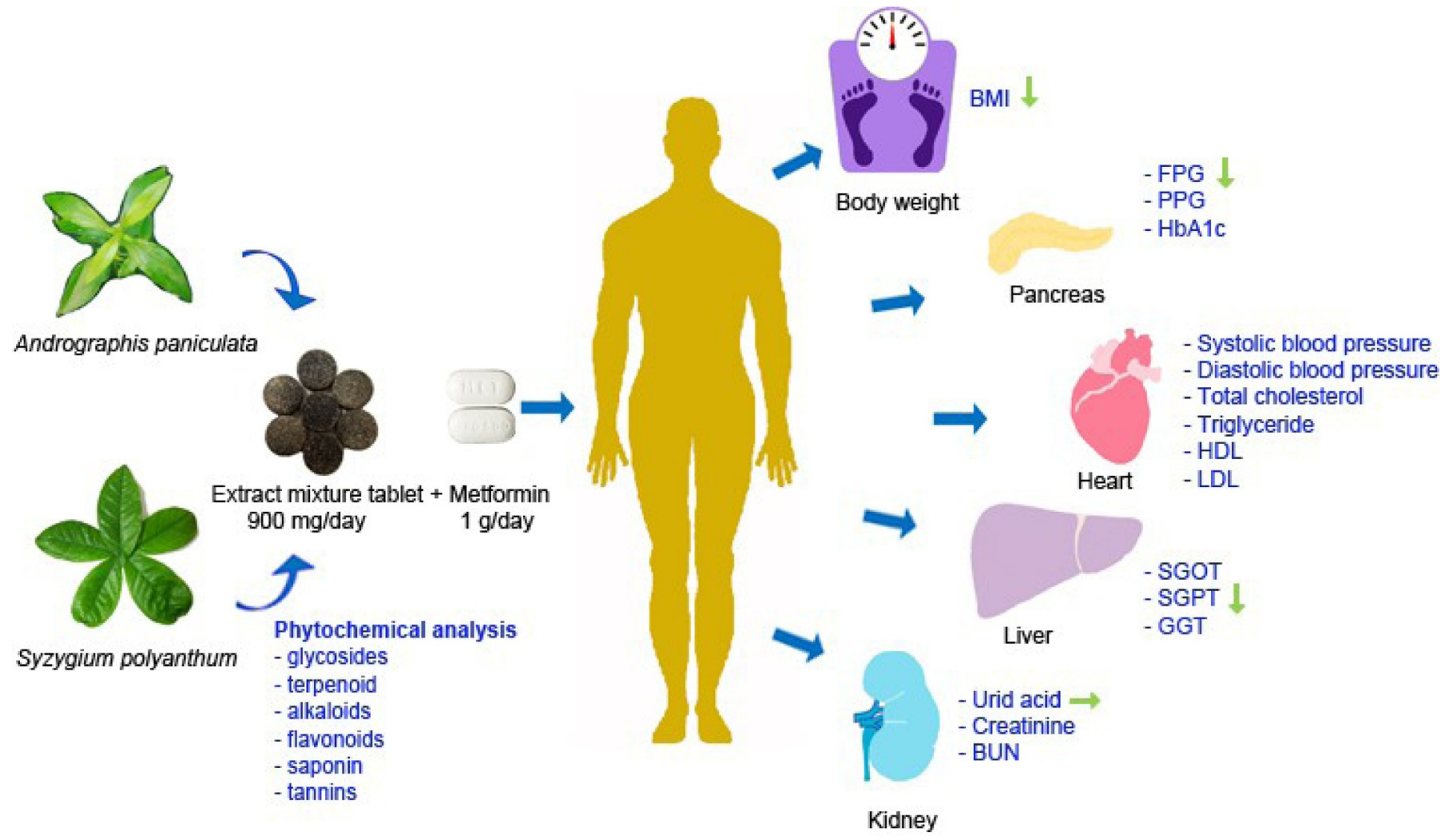

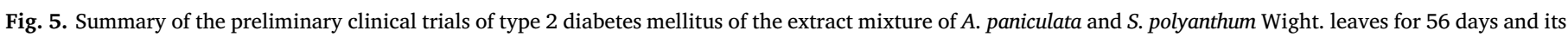
phytochemical analysis.

Catherina Widjajakusuma performed the statistical analysis, and managed the literature searches. Lucia Hendriati formulated and prepared all tablet used in the clinical trials. Elisabeth Catherina Widjajakusuma, Ferawati, Martha Ervina and Senny Yesery Esar conducted the phytochemical analysis. Sumi Wijaya, Lisa Soegianto, Senny Yesery Esar, Tirza Lang, and Cindy Heriyanti carried out TLC and HPLC analysis. Sumi Wijaya performed GC analysis. Arijanto Jonosewojo and Widayat Sastrowardoyo were involved in planning, study design and preparing the study protocol of the clinicial trials. Adrianta Surjadhana participated in planning study protocol. Lucia Hendriati formulated tablets of the extract mixture. Arijanto Jonosewojo, Widayat Sastrowardoyo, Nadia Monita, Nafdsu Makhmudatul Muna, Rachma Pantja Fajarwati were involved in recruiting and conducting the human trial. Elisabeth Catherina Widjajakusuma analyzed, interpreted all the data from the study and wrote and edited the paper.

\section{Acknowledgments}

Elisabeth Catherina Widjajakusuma received a grant from Ministry of Research Technology and Higher education with grant number RT2012-94 and from Directorate General of Higher Education with grant number $207 \mathrm{a} / \mathrm{WM} 01.5 / \mathrm{N} / 2012$ to support this study.

\section{Supplementary materials}

Supplementary material associated with this article can be found, in the online version, at doi:10.1016/j.phymed.2018.07.002.

\section{References}

Agarwal, R., Sulaiman, S.A., Mohamed, M., 2005. Open label clinical trial to study adverse effects and tolerance to dry powder of the aerial part of Andrographis paniculata in patients type 2 with diabetes mellitus. Malays. J. Med. Sci. 12, 13-19.

Akhtar, M.T., Sarib, M.S.B.M., Ismail, I.S., Abas, F., Ismail, A., Lajis, N.H., Shaari, K.,
2016. Anti-diabetic activity and metabolic changes induced by Andrographis paniculata plant extract in obese diabetic rats. Molecules 21, 1-18. https://doi.org/10. 3390/molecules21081026.

Aksay, E., Yanturali, S., Bayram, B., Hocaoğlu, N., Kiyan, S., 2007. A rare side effect of metformin: metformin-induced hepatotoxicity. Turk. J. Med. Sci. 37, 173-175.

Anggowati, R., Sukrasno, A.K.I, 2004. Telaah absorpsi ekstrak daun salam [Syzygium polyanthum (Wight) Walp.] berefek hipoglisemik pada tikus. Sekolah Farmasi ITB. http://bahan-alam.fa.itb.ac.id.

Artanti, N., Tachibana, S., Kardono, L.B.S., Sukiman, H., 2012. Isolation of $\alpha$-glucosidase inhibitors produced by an endophytic fungus, Colletotrichum sp. TSC13 from Taxus sumatrana. Pak. J. Biol. Sci. 15, 673-679.

Babich, M.M., Pike, I., Shiftman, M.L., 1998. Metformin induced acute hepatitis. Am. J. Med. 104, 490-492.

Bahmani, M., Zargaran, A., Rafieian-Kopaei, M., Saki, K., 2014. Ethnobotanical study of medicinal plants used in the management of diabetes mellitus in the Urmia, Northwest Iran. Asian Pac. J. Trop. Med. 7, S348-S354.

Balap, A., Lohidasan, S., Sinnathambi, A., Mahadik, K., 2017. Herb-drug interaction of Andrographis paniculata (Nees) extract and andrographolide on pharmacokinetic and pharmacodynamic of naproxen in rats. J. Ethnopharmacol. 195, 214-221.

Bernal-Lopez, M.R., Tinahones, F.J., Andrade, R.J., Gomez-Huelgas, R., 2012. Metformininduced hepatotoxicity. Diabetes Care. 35, e21.

Bowling, F.L., Rashid, S.T., Boulton, A.J.M., 2015. Preventing and treating foot complications associated with diabetes mellitus. Nat. Rev. Endocrinol. 11, 606-616.

Chan, J.C., Malik, V., Jia, W., Kadowaki, T., Yajnik, C.S., Yoon, K.H., Hu, F.B., 2009. Diabetes in Asia: epidemiology, risk factors, and pathophysiology. JAMA 301, 2129-2140.

Danaei, G., Finucane, M.M., Lu, Y., Singh, G.M., Cowan, M.J., Paciorek, C.J., Lin, J.K., Farzadfar, F., Khang, Y.H., Stevens, G.A., Rao, M., Ali, K.A., Riley, L.M., Robinson, C.A., Ezzati, M., 2011. National, regional, and global trends in fasting plasma glucose and diabetes prevalence since 1980: systematic analysis of health examination surveys and epidemiological studies with 370 country years and 2.7 million participants. Lancet North Am. Ed. 378, 31-40.

Dandu, A.M., Inamdar, N.M., 2009. Evaluation of beneficial effects of antioxidant properties of aqueous leaf extract of Andrographis paniculata in STZ-induced diabetes. Pak. J. Pharm. Sci. 22, 49-52.

DeFronzo, R., Fleming, G.A., Chen, K., Bicsak, T.A., 2015. Metformin-associated lactic acidosis: current perspectives on causes and risk. Metabolism 65, 20-29.

Deutsch, M., Kountouras, D., Dourakis, S.P., 2004. Metformin hepatotoxicity. Ann. Intern. Med. 140, W25.

Golay, A., 2008. Metformin and body weight. Int. J. Obes. 32, 61-72.

Goldstein, B.J., Pans, M., Rubin, C.J., 2003. Multicenter, randomized, double-masked, parallel-group assessment of simultaneous glipizide/metformin as second-line pharmacologic treatment for patients with type 2 diabetes mellitus that is inadequately 
controlled by a sulfonylurea. Clin. Ther. 25, 890-903.

Gupta, R.C., Chang, D., Nammi, S., Bensoussan, A., Bilinski, K., Roufogalis, B.D., 2017. Interaction between antidiabetic drugs and herbs: an overview of mechanisms of action and clinical implications. Diabetol. Metab. Syndr. 9, 1-12.

Hassan, H., Nor, M., Ravi, N., Norazilamaskam, L.H.T.B., 2015. Phytochemicals screening, antioxidant activity and frying quality as affected by aqueous extract of Malaysian Serai Kayu (Eugenia polyantha). Int. J. Res. Appl. 3, 89-98.

Hendriati, L., Ferawati, S., Jonosewojo, A., Widjajakusuma, E.C., 2011. Optimasi kadar PVP K-30 sebagai pengikat dan krospovidon sebagai disintegran pada tablet sambiloto-salam. Jurnal Bahan Alam Indonesia 7, 382-386.

Hendriati, L., Kresnamurti, A., Surjadhana, F., Jonosewojo, A., 2010. Hypoglycemic activity of water and ethanol extract of Andrographis panicula Burn Ness. with glucose tolerance test in rats. In: International Conference on Medicinal Plants Surabaya. Indonesia. pp. 208.

Holman, R., 2007. Metformin as first choice in oral diabetes treatment: the UKPDS experience. J. Annu. Diabetol. Hotel Dieu 13-20.

Hossain, M.S., Urbi, Z., Sule, A., Rahman, K.M.H., 2014. Andrographis paniculata (Burm. f.) Wall. ex Nees: a review of ethnobotany, phytochemistry, and pharmacology. Sci. World J.

Hosseinzadeh, H., Tafaghodi, M., Abedzadeh, S., Taghiabadi, E., 2014. Effect of aqueous and ethanolic extracts of Pimpinella anisum L. seeds on milk production in rats. J. Acupunct. Meridian Stud. 7, 211-216.

Hosseinzadeh, H., Tafaghodi, M., Mosavi, M.J., Taghiabadi, E., 2013. Effect of aqueous and ethanolic extracts of Nigelia sativa seeds on milk production in rats. J. Acupunct. Meridian Stud. 6, 18-23.

Inzucchi, S.E., Lipska, K.J., Mayo, H., Bailey, C.J., McGuire, D.K., 2014. Metformin in patients with type 2 diabetes and kidney disease: a systematic review. JAMA 312, $2668-2675$.

Jayakumar, T., Hsieh, C.Y., Lee, J.J., Sheu, J.R., 2013. Experimental and clinical pharmacology of Andrographis paniculata and its major bioactive phytoconstituent andrographolide. Evid. Based Complement. Altern. Med. 2013, 1-16.

Ju, B.J., Kim, S.C., 2008. Comparison between ethanolic and aqueous extracts from Chinese juniper berries for hypolipidemic effects in alloxan-induced diabetic rats. J. Ethnopharmacol. 115, 110-115.

Jutiviboonsuk, A., 2015. The role of Andrographis paniculata (Burm.f.) Wall. ex Nees in drug interactions. Siriraj Med. J. 67, 196-204.

Ketema, E.B., Kibret, K.T., 2015. Correlation of fasting and postprandial plasma glucose with $\mathrm{HbA1c}$ in assessing glycemic control; systematic review and meta-analysis. Arch. Public Health 73, 1-9.

Komalasari, T., Harimurti, S., 2015. A review on the anti-diabetic activity of Andrographis paniculata (Burm. f.) Nees based in-vivo study. Int. J. Public Health Sci. 4, 256-263.

Kooti, W., Farokhipour, M., Asadzadeh, Z., Ashtary-Larky, D., Asadi-Samani, M., 2016. The role of medicinal plants in the treatment of diabetes: a systematic review. Electron. Physician 8, 183201842.

Krishnamoorthy, P., Kalaiselvan, D., 2016. Isolation of plasticizer compound 1, 2-benzenedicarboxlyic acid in leaf extract of Andrographis paniculatas. IJIRSET 5, 4985-4991.

Kumar, M., Gani, M.S., 2017. Phytochemical investigation, GC- MS analysis, invitro an timicrobial and antioxidant property of Andrographis paniculata. Int. J. Curr. Trends Sci. Technol. 7, 20171-20177.

Kusuma, I.W., Kuspradini, H., Arung, E.T., Aryani, F., Min, Y.H., Kim, J.S., Kim, Y.U., 2011. Biological activity and phytochemical analysis of three Indonesian medicinal plants, Murraya koenigii, Syzygium polyanthum and Zingiber purpurea. J. Acupunct. Meridian Stud. 4, 75-79.

Lanawati, F., Ferawati, W.E.C., Soemartojo, J., Harti, S., 2012. Jamu Pahitan. Widya Mandala Catholic University Surabaya, Surabaya.

Lee, A., Morley, J.E., 1998. Metformin decreases food consumption and induces weight loss in subjects with obesity with type II non-insulin-dependent diabetes. Obesity 6 , $47-53$.

Lelono, R.A., Tachibana, S., Itoh, K., 2009. In vitro antioxidative activities and polyphenol content of Eugenia polyantha Wight grown in Indonesia. Pak. J. Biol. Sci. 12, 1564-1570.

Lheureux, P.E., Lheureux, O.F., Penaloza-Baeza, A., 2009. Metformin toxicity. Eur. J. Emerg. Med. 16, 348-349.

Limyati, D.A., Juniar, B.L., 1998. Jamu Gendong, a kind of traditional medicine in Indonesia: the microbial contamination of its raw materials and endproduct. J. Ethnopharmacol. 63, 201-208.

Marre, M., Howlett, H., Lehert, P., Allavoine, T., 2002. Improved glycaemic control with metformin-glibenclamide combined tablet therapy (Glucovance) in Type 2 diabetic patients inadequately controlled on metformin. Diabet. Med. 19, 673-680.

Mirhoseini, M., Khodai, M., Rafieian-Kopaei, M., 2013. Medicinal plants, diabetes mellitus and urgent needs. J. Herbmed. Pharmacol. 2, 53-54.

Mourão-Júnior, C.A., Sá, J.R., Guedes, O.M.S., Dib, S.A., 2006. Effects of metformin on the glycemic control, lipid profile, and arterial blood. Braz. J. Med. Biol. Res. 489-494.

Nair, A.B., Jacob, S., 2016. A simple practice guide for dose conversion between animals and human. J. Basic Clin. Pharm. 7, 27-31.

Nasir, A., Abubakar, M.G., Shehu, R.A., Aliyu, U., Toge, B.K., 2013. Hepatoprotective effect of the aqueous leaf extract of Andrographis paniculata Nees against carbon tetrachloride - induced hepatotoxicity in rats. Nigerian J. Basic Appl. Sci. 21, 45-54.

Nasri, H., Shirzad, H., Khodai, M., Rafieian-Kopaei, M., 2015. Antioxidant plants and diabetes mellitus. J. Res. Med. Sci. 20, 491-501.

Niranjan, A., Tewari, S.K., Lehri, A., 2010. Biological activities of Kalmegh (Andrographis paniculata Nees) and its active principles - a review. Indian J. Nat. Product Resour. 125-135.

Nizmawardini, Y., Endang, H., Djunaidi, R., Sari, S.P., 2013. The effect of Andrographis paniculata extract capsules on blood glucose level in patients with type 2 diabetes mellitus. Int. J. Curr. Res. 5, 578-581.

Pan, Y., Abd-Rashid, B.A., Ismail, Z., Ismail, R., Mak, J.W., Pook, P.C., Er, H.M., Ong, C.E., 2011. In vitro modulatory effects of Andrographis paniculata, Centella asiatica, and Orthosiphon stamineus on cytochrome P450 2C19 (CYP2C19). J. Ethnopharmacol, $133,881-887$.

Pan, Z., Wang, S.-K., Cheng, X.-L., Tian, X.-W., Wang, J., 2016. Caryophyllene oxide exhibits anti-cancer effects in MG-63 human osteosarcoma cells via the inhibition of cell migration, generation of reactive oxygen species and induction of apoptosis. Bangladesh J. Pharmacol. 11, 817-823.

Panda, S., Bandyopadhyay, P.K., 2013. Chemical information from GC-MS studies of methanolic leaf extract of Andrographis paniculata and Datura metel and their antibacterial activity against isolated Pseudomonas aeruginosa (PB112) strain. Int. J. Pharm. Bio. Sci. 4, 900-915.

Paolisso, G., Amato, L., Eccelente, R., Gambardella, A., Tagliamonte, M.R., Varricchio, G., Carella, C., Giugliano, D., D'Onofrio, F., 1998. Effect of metformin on food intake in obese subjects. Eur. J. Clin. Invest. 28, 441-446.

Ponssen, H.H., Elte, J.W., Lehert, P., Schouten, J.P., Bets, D., 2000. Combined metformin and insulin therapy for patients with type 2 diabetes mellitus. Clin. Ther. 22 , 709-718.

Rahim, E.N.A.A., Ismail, A., Omar, M.N., Rahmat, U.N., Ahmad, W.A.N.W., 2018. GC-MS analysis of phytochemical compounds in Syzygium polyanthum leaves extracted using ultrasound-assisted method. Pharmacogn. J. 10, 110-119.

Rahimi-Madiseh, M., Heidarian, E., Rafieian-Kopaei, M., 2014. Biochemical components of Berberis lycium fruit and its effects on lipid profile in diabetic rats. J. HerbMed. Pharmacol. 3, 15-19.

Rajasekaran, A., Arivukkarasu, R., Mathew, L., 2016. A systematic comprehensive review on therapeutic potential of Andrographis paniculate (Burm. f.) Wall. ex Nees. J. Pharmacognosy Phytochem. 5, 189-199.

Ramachandran, A., Snehalatha, C., Shetty, A.S., Nanditha, A., 2012. Trends in prevalence of diabetes in Asian countries. World J. Diabetes 3, 110-117.

Roy, S., Rao, K., Bhuvaneswari, C., Giri, A., Mangamoori, L.N., 2010. Phytochemical analysis of Andrographis paniculata extract and its antimicrobial activity. World. J. Microbiol. Biotechnol. 26, 85-91.

Shalini, V.B., Narayanan, J.S., 2015. Characterization studies on medicinal plant of Andrographis paniculata (NEES). J. Med. Plants Stud. 3, 96-102.

Sharma, M., Sharma, A., Tyagi, S., 2012. Quantitative HPLC analysis of andrographolide in Andrographis paniculata at two different stages of life cycle of plant. Acta Chim. Pharm. Indica 2, 1-7.

Singh, N., 2010. Comparison of both water and ethanol extracts prepared from Echinacea purpurea and Echinacea angustifolia on the response to Influenza A/PR/8/34 infection in mice. Graduate Theses and Dissertations, Iowa State University. http://lib. dr.iastate.edu/etd/11290.

Singh, P., Srivastava, M.M., Khemani, L.D., 2009. Renoprotective effects of Andrographis paniculata (Burm. f.) Nees in rats. Ups. J. Med. Sci. 114, 136-139.

Srivastava, A., Misra, H., Verma, R.K., Gupta, M.M., 2004. Chemical fingerprinting of Andrographis paniculata using HPLC, HPTLC and densitometry. Phytochem. Anal. 15, 280-285.

Studiawan, H., Santosa, M.H., 2005. Uji aktivitas penurun glukosa darah ekstrak daun Eugenia polyantha pada mencit yang diinduksi alloxan. Media Kedokteran Hewan 21, 62-65.

Suharmiati, S., Roosihermiatie, B., 2012. Studi pemanfaatan dan keamanan kombinas metformin dengan ekstrak campuran Andrographis paniculata and Syzygium polyanthum untuk pengobatan diabetes mellitus (preliminary study). Buletin Penelitian Sistem Kesehatan 15, 110-119.

Sumono, A., Wulan, A., 2008. The use of bay leaf (Eugenia polyantha Wight.) in dentistry. Dent. J. 41, 147-150.

Sundari, M., 2010. Studi beberapa dosis infus daun salam (Syzygium polyanthum Wight Walp) sebagai antidiare pada mencit (Mus musculus). Jurnal Farmasains 1.

Surender, S., Vinod, N., Sweety, J., Gupta, Y.K., 2008. Evaluation of anti-inflammatory activity of plant lipids containing $\alpha$-linolenic acid. Indian J. Exp. Biol. 46, 453-456.

Sutha, D., Jegathambigai, R., Kumar, P., Sivaramakrishnan, S., 2010. A study on the hepatoprotective effect of Andrographis paniculata (Burm.F). Nees on mice. J. Phytol. $2,25-30$.

Thangavel, M., Umavathi, S., Thangam, Y., Thamaraiselvi, A., Ramamurthy, M., 2015. GC-MS analysis and larvicidal activity of Andrographis paniculata (Burm.F) Wall. Ex Nees. against the Dengue vector Aedes aegypti (L) (Diptera: Culicidae). Int. J. Curr. Microbiol. Appl. Sci 4, 392-403.

Trivedi, N.P., Rawal, U.M., 2001. Hepatoprotective and antioxidant properties of Andrographis paniculata (Nees) in BHC inducer liver damage in mice. Indian J. Exp. Biol. 39, 41-46.

Udobre, A.S., Udoh, A.E., Etim, E.I., Umoh, U.F., Johnson, E.C., 2016. GC-MS analysis of six bioactive compounds isolated from the ethanol leaf extract of Andrographis paniculata (Acanthaceae). Chem. Res. J. 1, 6-10.

Vagula, M., Devi, S.S., 2008. Hepatotoxicity of antidiabetic drugs. US Pharm. 33, 3-9.

Vasantha, S., Suburamaniyan, A., Madhumathi, V., Abubacker, M.N., 2013. Gas chromatography-mass spectrometry (GC-MS) analysis of ethanolic leaf extract of Andrographis paniculata Nees. Int. J. Med. Biosci. 2, 16-20.

Vetriselvan, S., Middha, A., 2016. Potential action of Andrographis paniculata against chronic ethanol consumption induced liver toxicity in experimental rats. Eur. J. Med. Plants 12, 1-9.

Wahyono, D., Susanti, 2008. Aktivitas hipoglikemik ekstrak etanolik daun salam dan pengaruhnya terhadap stimulasi parasimpatik pada kelinci jantan yang dibebani glukosa. Majalah Obat Tradisional 13.

Wendy, L.B., Maruthur, N.M., Singh, S., Segal, J.B., Wilson, L.M., Chatterjee, R. Marinopoulos, S.S., Puhan, M.A., Ranasinghe, P., Block, L., Nicholson, W.K., Hutfless, 
S., Bass, E.B., Bolen, S., 2011. Comparative effectiveness and safety of medications for type 2 diabetes: an update including new drugs and 2-drug combinations. Ann. Intern. Med. 154, 602-613.

Widharna, R.M., Ferawati, Tamayanti, W.D., Hendriati, L., Widjajakusuma, E.C., 2015 Antidiabetic effect of the aqueous extract mixture of Andrographis paniculata and Syzygium polyanthum leaf. Eur. J. Med. Plants 6, 82-91.

Widyawati, T., Yusoff, N.A., Asmawi, M.Z., Ahmad, M., 2015. Antihyperglycemic effect of methanol extract of Syzygium polyanthum (Wight.) leaf in streptozotocin-induced diabetic rats. Nutrients 7, 7764-7780.

Xu, H.W., Dai, G.F., Liu, G.Z., Wang, J.F., Liu, H.M., 2007. Synthesis of andrographolide derivatives: a new family of alpha-glucosidase inhibitors. Bioorg. Med. Chem. 15,
4247-4255.

Xu, J., Huang, S., Luo, H., Li, G., Bao, J., Cai, S., Wang, Y., 2010. QSAR studies on andrographolide derivatives as alpha-glucosidase inhibitors. Int. J. Mol. Sci. 11, 880-895.

Zheng, L., 2016. Metformin as a rare cause of drug-induced liver injury, a case report and literature review. Am. J. Ther. 23, e315-e317.

Zou, W., Xiao, Z., Wen, X., Luo, J., Chen, S., Cheng, Z., Xiang, D., Hu, J., He, J., 2016. The anti-inflammatory effect of Andrographis paniculata (Burm. f.) Nees on pelvic inflammatory disease in rats through down-regulation of NF-kB pathway. BMC Complement. Alternat. Med. 16, 1-7. 